\section{Comprehensive Biochemistry}

Vol. 7, Part 1: Proteins. Edited by Marcel Florkin and Elmer H. Stotz. Pp. xii +280. (Amsterdam, London and New York: Elsevier Publishing Company, 1963.) $75 s$.

GEVERAL treatises on proteins have appeared in recent S years, and most have been considerably larger than this volume, although it should be noted that there are further sections on individual proteins in the succeeding volume in this series. The present treatment accorded to proteins is neither exhaustive nor exhausting. Most of the book is well written, but there are certain features which merit oriticism. The omission of any account of the general methods of synthesizing peptides is to be deplored, since it is in this field that organic chemists and biochemists have combined so effectively to establish relationships between the biological activity and structure of polypeptides. The first two chapters deal with the occurrence, classification, preparation, and analysis of proteins (E. G. Young) and the chemical methods of determining and modifying protein structure (H. Fraenkel-Conrat).

The remainder of the book is devoted to physical methods of investigating proteins. The topics covered include acid-base properties and electrophoresis of proteins (R. Trautman), protein interactions and denaturation (H. A. Scheraga), osmosis (R. L. Baldwin), sedimentation, diffusion and partial specific volume (K. O. Pedersen), and spacial configuration in proteins (D. W. Green). This volume has apparently been in preparation for a considerable time. Trautman and Scheraga admit that their chapters were written in 1960-61, and it is fairly obvious that the remainder of the book is of similar vintage. One of the reasons given by the editors for publishing this treatise in numerous small volumes was the desire to provide a contemporary picture of biochemistry. This aim has been only partially successful in this volume. Some of the authors have attempted to make amends when the book was in proof by directing attention to more recent developments and citing additional references. It is to be hoped that later volumes will not suffer a similar delay in publication, for this kind of comprehensive survey of biochemistry is desperately needed.

D. T. ELMORF

\section{La Tolérance Acquise et la Tolérance Naturelle a l'Égard de Substances Antigéniques Définies} Colloques Internationaux du Centre National de la Recherche Scientifique, No. 116, Royaumont, 25-28 Juin, 1962. Pp. 490. (Paris: Éditions du Centre National de la Recherche Scientifique, 1963.) n.p.

T HE 44 participants in the Royaumont Symposium included two from Eastern Europe. Of the 24 papers, 19 are in English and 5 in French; one of the latter carries an English summary.

It was generally accepted by the speakers that a state of tolerance may be induced when the dose of antigen is sufficiently large in relation to the number of immunologically competent cells present in the injected animal. Factors which bring this about are discussed in the first group of papers - size of dose, neonatal paucity of immunologically competent cells, thymectomy, the injection of Fround's adjuvant, X-irradiation and the administration of 6-mercaptopurine, thioguanine, folic rocid antagonists or alkylating agents.

Three papers discuss methods of suppression or abrogation of tolerance-X-irradiation, the injection of antibody, the transplantation of immunologically competent cells and immunization with related antigens. Natural tolerance to autologous antigens is considered in three papers, one of which examines the failure of natural tolerance in cases of allergic encephalitis. Several papers cover other aspects, such as the types of cells involved in immunological reactions, the effects of thymectomy, the non-specific globulin response to the injection of Freund's adjuvant and tolerance to chemical antigens. The final two papers discuss theories of immunological reactions.

A feature of great value in this volume is the verbatim reporting of audience discussions of each paper, and the whole symposium closes with an extensive general discussion. As would be expected, the meeting together of this group of distinguished immunologists stimulated much discussion and speculation, which ranged widely within the field of theoretical immunology. Yet the presentation is lucid. The book is recommended both to specialists in the field and to those whose experience may be less, but whose interest is keen.

\section{A Guide to Subcellular Botany}

An Introduction to the Structure and Functions of Plant Cells in the Light of Modern Developments. By C. A. Stace. Pp. xi + 148. (London: Longmans, Green and Co., Ltd., 1963.) $15 s$.

7 HIS little book deals with the structure (physical and chemical) and functions of the various parts of the plant cell, and naturally draws heavily on the new information provided by the electron microscope. It is written at a level held to be suitable for school sixth-formers, students in their early years at universities, and teachers. The book is in three sections devoted respectively to plant compounds, cell structure, and genes and enzymes. Each of these is divided into sub-sections which are not headed as chapters but are so described in cross-references; a numerical reference might have been tidier.

Mr. Stace is well informed and writes interestingly and concisely, aided by clear diagrams. No attempt is made to gloss over the many gaps in existing knowledge of the ultrastructure of cells. Misprints and faults in expression are few, though a sentence on $p .108$ can be read to imply that it is in order to ignore facts which happon to be inconsistent with a particular hypothesis. The use of the term 'dogma' in reference to the concept that DNA is the ultimate genetic particle is open to several objectionssurely 'theory' or 'hypothesis' can continue to serve in such instances. Some reference to the possible bearing of the new information concerning cell structure on the uptake of water and solutes would havo been welcome.

Though it is becoming customary for general botanical text-books to include some description of sub-collular structure, there was undoubtedly a need for the fuller treatment possible in a book devoted entirely to these aspects, and many botanists will be grateful to the author for filling this gap. Whether school pupils or even university students in their early years will have the time to master so much detail is debatable. $\quad$ G. BOND

\section{Boolean Algebra}

(The Commonwealth and International Library of Science, Technology, Engineering and Liberal Studies.) Mathematies Division. Vol. 6. By Prof. R. L. Goodstein. Pp. vii +140 . (Oxford, London, Paris and Frankfurt: Pergamon Press; New York: The Macmillan Company, 1963.) 12s. $6 d$.

T $\mathrm{N}$ his remarkable essay, Mathematical Analysis of Logic (1847), George Boole gave the first really suceessful reduction of propositional logic to an algebraic calculus. The same caleulus supplies an algebra of sets or classos, perhaps a more concrete instance for the novice, and Prof. Goodstein begins his tract hero. $\mathrm{He}$ then procoeds to discuss various axiomatizations of the system, returning to the algebra of sentences or propositions as another exemplification. The last chapter deals with partially ordered sets and lattices. The author is primarily interested in structure, so that the book forms a good introduction to the elegant austerities of modern abstract algebra. The anatomy of Boolean algebra is clearly displayed and expounded, and the reader can add a good deal of flesh by working through the numerous examples, for which the generosity of the author has provided full solutions at the end of the volume. T. A. A. BROADBENT 